\title{
Stage-Limited Expression of myc Oncoprotein in the Human Ovary during Follicular Growth, Regression and Atresia
}

\author{
Shangwei LI, Takeshi MARUO, Cecilia A. LADineS-LLAVE, \\ Hitoshi KONDO, And Matsuto MOCHIZUKI \\ Department of Obstetrics and Gynecology, \\ Kobe University School of Medicine, Kobe 650, Japan
}

\begin{abstract}
The cytologic localization and cellular levels of myc oncoprotein in the human ovary during follicular growth, regression and atresia were examined by the avidin/biotin immunoperoxidase method with a specific antibody to myc oncoprotein. In primordial follicles, only the oocyte showed intense immunostaining for $m y c$ protein, whereas the granulosa cells were negative for the staining. In preantral follicles, both the oocyte and granulosa cells were moderately immunostained for myc protein. In antral and preovulatory follicles, there was no appreciable staining for myc protein in the granulosa or theca cells, while myc protein staining in the oocyte persisted with less intensity. It is of interest that $m y c$ protein expression in granulosa cells was apparent only during the preantral follicle stage. Corpora lutea during the early and mid luteal phase were negative for myc protein staining, whereas in regressing corpora lutea during the late luteal phase, peripheral theca lutein cells adjacent to the central core of scar tissue were immunostained for myc protein. Corpora albicans showed no staining for $m y c$ protein. In atretic follicles, granulosa cells and theca interna cells demonstrated positive staining for $m y c$ protein. Ovarian stromal cells were negative for the immunostaining throughout the menstrual cycle. This demonstrates that myc protein is expressed in a stage-limited manner in the human ovary during follicular growth and regression. The abundant expression of myc protein in the oocyte at the primordial and preantral follicle stages and in the granulosa cells at the preantral follicle stage suggests a role for myc expression in the initial growth of the oocyte as well as in the autonomous growth of granulosa cells during the preantral stage seemingly independent of gonadotropic stimulation. Furthermore, notable expression of myc protein in the granulosa cells and theca interna cells of atretic follicles and in the peripheral theca lutein cells of regressing corpora lutea implies the possible participation of $m y c$ expression in remodelling the ovarian local tissue following atresia and luteolysis in the human ovary.
\end{abstract}

Key words: myc Oncoprotein, Ovary, Folliculogenesis, Oocyte, Atresia, Luteolysis.

(Endocrine Journal 41: 83-92, 1994)

OVARIAN folliculogenesis is characterized in part by marked proliferation of granulosa cells. Actually, the granulosa cell which supports the developing oocyte is one of the most rapidly growing normal cell types known, and plays a key role in the functional maturation of the ovarian follicle. Beginning as a single layer of flattened

Received: October 4, 1993

Accepted: November 19, 1993

Correspondence to: Dr. Takeshi MARUO, Department of Obstetrics and Gynecology, Kobe University School of Medicine, 7-5-1 Kusunoki-cho, Chuo-ku, Kobe 650, Japan pregranulosa cells in primordial follicles, granulosa cells actively proliferate until at the time of ovulation they form a layer 6-10 cells deep. The proliferation of granulosa cells is necessary not only for follicular growth but also for creation of the unique microenvironment for oocyte maturation. Thus, the factors responsible for regulating the growth of the granulosa cell population are critical for the maintenance of fertility in the female. However, these factors have not been completely elucidated.

Although the primary role of follicle stimulating 
hormone (FSH) in granulosa cell replication as well as differentiated function is well established [1], several growth factors such as thyroid hormone [2-4], insulin [5-8], insulin-like growth factor-I (IGF-I) [9-11], epidermal growth factor (EGF) [1216] and fibroblast growth factor (FGF) [17] have been evaluated for their potential as endocrine, paracrine and/or autocrine regulators of granulosa cell growth and function. On the other hand, there is now abundant evidence indicating that a number of oncogenes are related to growth factors and their receptors. Several lines of recent evidence suggest a role for $m y c$ oncogene in cell proliferation [18-20]. Despite the wealth of information on various growth factors playing a role as intraovarian regulators of granulosa cell growth and function, little is known about the possible involvement of the myc oncogene in ovarian follicular development.

In the present study, attention was therefore focused on the possible expression of myc oncoprotein in human ovaries at different stages of follicular development. The stage-limited cytologic localization of $m y c$ protein observed in follicular compartments over the course of follicular growth, regression and atresia was discussed in relation to the possible physiologic role of $m y c$ expression in the human ovary.

\section{Materials and Methods}

\section{Tissue preparation}

Ovarian tissues were obtained from women with regular menstrual cycles who underwent abdominal hysterectomy with uni- or bilateral salpingooophorectomy for a variety of gynecological conditions including leiomyoma, endometriosis and early cervical neoplasia. The collection of these tissues has been approved by the Institutional Review Board. These patients ranged in age from 32 to 41 years with a mean age of 35 years. Informed consent was obtained from each patient before surgery for the use of ovarian tissues for immunohistochemical studies. Each ovarian specimen was examined by a pathologist for histological evaluation and dating of the endometrium. Endometrial tissues were obtained either from the extirpated uteri or from endometrial biopsies, and the criteria for the day of the menstrual cycle were based on en- dometrial histological dating according to the method of Noyes et al. [21]. Ovaries were graded into six categories: early follicular, mid follicular, late follicular, early luteal, mid luteal, and late luteal phases of the menstrual cycle. On histological examination, individual follicles were categorized as primordial, preantral, antral or preovulatory, and atretic follicles. Of the 36 patients included in this study, 9 had corpora lutea at the early (cycle days 14-18, n=3), mid (cycle days 19$24, n=3$ ) and late (cycle days 25-28, $n=3$ ) stages of the luteal phase.

Ovarian tissues obtained were fixed in $4 \%$ buffered neutral formalin, dehydrated and embedded in paraffin. Sections, 5 to $6 \mu \mathrm{m}$ in thickness, were deparaffinized and followed by standard histologic techniques.

Immunohistochemical staining was performed by avidin/biotin immunoperoxidase techniques with the use of a polyvalent immunoperoxidase kit (Omnitags, Lipshaw, Michigan) as previously described by Maruo and Mochizuki [20]. An affinitypurified sheep polyclonal antibody to human myc oncoprotein (Cambridge Research Biochemicals, Cheshire, UK) was used as the primary antibody in this study. The anti-myc protein antibody $(250 \mu \mathrm{g}$ $\operatorname{IgG} / 250 \mu l$ ) was diluted 1: 500 before use. The first incubation with primary antibody was followed by the second incubation with biotinylated polyvalent antibody, and by the third incubation with avidinhorseradish peroxidase. A chromogenic reaction was then developed by incubating with a freshly prepared solution of tetrahydrochloridediaminobenzidine and hydrogen peroxide. The sections were then counterstained with Harris hematoxylin, mounted with glycerine phosphate buffer solution, and examined microscopically.

The following control procedures were undertaken to assure specificity of the immunologic reactions. Adjacent control sections were subjected to the same immunoperoxidase method with the exception that the primary antibody to myc protein was replaced by nonimmune sheep IgG (Miles, Erkhart, Indiana) at the same dilution as the specific antibody. In the abovementioned control, no positive staining was observed. Furthermore, preabsorption of the anti-myc oncoprotein antibody with human myc peptide (OP-11-3030, Cambridge Research Biochemicals, Cheshire, UK) at a ratio of $1 \mu \mathrm{g}$ of IgG of antibody to $10 \mathrm{ng}$ of human 
myc peptide resulted in the abolishment of positive immunostaining of the ovarian follicles for $m y c$ protein.

The intensity of immunostaining was evaluated by repeated staining of the same specimens and by more than two observers. It was graded as $(-)$ for no immunostaining, $(+)$ for weak but definitely detectable immunostaining, $(++)$ for moderate immunostaining, and $(+++)$ for intense immunostaining.

\section{Results}

For the follicular phase of the menstrual cycle, the immunocytologic localization and cellular levels of $m y c$ oncoprotein in the human ovaries at the different stages of follicular growth are given in Table 1.

In primordial follicles, only the oocyte showed intense immunostaining for myc protein whereas the surrounding flattened pregranulosa cells and stromal cells were negative for the staining (Fig. 1A). The earliest stage of follicular growth at which the immunostaining for myc protein in granulosa cells became apparent was the preantral stage. In preantral follicles during the early follicular phase, both the oocyte and granulosa cells were moderately immunostained (Fig. 1A). Replacement of the primary antibody with nonimmune sheep IgG showed a lack of positive immunostaining of the oocyte and granulosa cells (data not shown). Abolishment of positive immunostaining of the oocyte and granulosa cells for $m y c$ protein was also observed by preincubation of the anti-myc protein antibody with human myc peptide (Fig. 1B).

In antral and preovulatory follicles during the mid and late follicular phase, only the oocyte persisted in the immunostaining for myc protein (Fig. 2). However, the staining intensity of the oocyte for $m y c$ protein in antral and preovulatory follicles was less than that in primordial and preantral follicles. No appreciable immunostaining for $m y c$ protein was observed in the granulosa cells, theca cells and stromal cells during the antral and preovulatory follicle stages.

Table 2 summarizes the immunocytologic localization and cellular levels of myc oncoprotein in luteal cells and the surrounding stromal cells over the course of the luteal phase of the menstrual cycle. In corpora lutea during the early and mid luteal phase, the lutein cells were negatively immunostained for myc protein (Fig. 3). However, in regressing corpora lutea during the late luteal phase, weak but appreciable immunostaining for $m y c$ protein was apparent only to the peripheral theca lutein cells adjacent to the central core of scar tissue (Fig. 4). Corpora albicans were totally negative for the immunostaining for $m y c$ protein (Fig. 5). The stromal cells showed no immunostaining for $m y c$ protein throughout the luteal phase.

In atretic follicles, the scattered granulosa cells and theca interna cells exhibited weak but definitely positive immunostaining for $m y c$ protein (Fig. 6). The stromal cells surrounding the atretic follicles had negligible immunostaining for $m y c$ protein.

\section{Discussion}

Morphologically, the ovarian follicle changes as it matures. The most immature stage is the primordial follicle which is the structure composed of

Table 1. Immunostaining for myc oncoprotein in follicular and stromal compartments at the different stages of follicular growth

\begin{tabular}{lcccc}
\hline Follicular stage & Oocyte & $\begin{array}{c}\text { Granulosa } \\
\text { cells }\end{array}$ & $\begin{array}{c}\text { Theca interna } \\
\text { cells }\end{array}$ & $\begin{array}{c}\text { Surrounding } \\
\text { stromal cells }\end{array}$ \\
\hline Primordial $(n=8)$ & +++ & - & & - \\
Preantral $(n=8)$ & ++ & ++ & - & - \\
Antral $(n=8)$ & + & - & - & - \\
Preovulatory $(n=3)$ & + & - & - & - \\
Atretic $(n=8)$ & & + & + & -
\end{tabular}

- , no immunostaining ; +, weak but definitely detectable immunostaining ; ++, moderate immunostaining ; +++, intense immunostaining. 
the oocyte, a single flattened granulosa layer, and a surrounding basement membrane. Growth of the primordial follicle to a preantral follicle entails enlargement of the oocyte and investment by at least two layers of granulosa cells. During this process, the flattened granulosa cells of the primordial follicle are replaced by cuboidal granulosa cells, and the follicle acquires an additional feature which is in the form of an external sheath of theca, concentric to the granulosa layer. The theca is first apparent in preantral follicles as a single layer of flattened stromal cells. The appearance of a number of irregular spaces between cells in the granulosa layer then marks the beginning of the second growth stage of the follicle. It is at the stage of the antral follicle. The distinguishing feature of the follicle at this stage is the development of a fluidfilled cavity (antrum). The accumulation of fluids is both the result of the secretion of mucopolysaccharides by granulosa cells and the transudation of plasma proteins from the newly acquired theca layer with its vasculature. Furthermore, the preovulatory follicle becomes increasingly vascularized as ovulation approaches. Simultaneously, follicles not selected for ovulation undergo atresia. Thus, once a follicle leaves the resting primordial pool, it continues to mature or succumbs to atresia [22].

It is evident that follicular growth and maturation beyond the preantral stage is primarily dependent on gonadotropic stimulation. FSH is indispensable for follicular growth during the antral stage, while LH is important particularly for the final stage of follicular maturation. The onset of gonadotropin-dependent follicular growth seems likely to be coincident with the time of establishment of the connection of the follicular apparatus (theca layer) to the peripheral bloodstream [23]. By contrast, in primordial follicles the vasculature is poorly developed. Eventually, the growth of the primordial follicle to a preantral follicle appears to be largely independent of gonadotropic stimulation, since follicles at various preantral stages of development are observed in the ovaries of hypophysectomized subjects and of patients with hypogonadotropic hypogonadism [24]. However, little is known about the factors responsible for the autonomous growth of the primordial follicle to a preantral follicle seemingly independent of gonadotropic stimulation.

The results of the present study have demon- strated for the first time that $m y c$ oncoprotein expression in human ovaries is confirmed to the oocyte and its surrounding granulosa cells at early stages of follicular development. Myc protein expression in the oocyte is highest in primordial follicles and decreases as the oocyte matures during follicular maturation. This suggests a vital role of $m y c$ expression in the initial growth of the oocyte in early folliculogenesis. On the other hand, myc oncoprotein expression in granulosa cells is pronounced only in preantral follicles. No appreciable expression of myc protein is apparent in the granulosa cells in either antral follicles or preovulatory follicles. It is therefore possible that the abundant expression of myc protein that we found in the granulosa cells only in preantral follicles indicates the involvement of $m y c$ expression in regulating the growth of preantral follicles.

This stage-limited expression of $m y c$ oncoprotein in the human ovaries during follicular development is of great interest in understanding the possible factors responsible for regulating the growth of ovarian follicles. Since the primordial and preantral stages are known to be gonadotropin-independent stages of follicular growth, the autonomous growth during the early stages of folliculogenesis seems to be regulated in part by $m y c$ oncogene expression. By contrast, during the antral and preovulatory follicle stages, pituitary gonadotropins take over the role in regulating granulosa cell proliferation and differentiation in synergy with various growth factors.

Following ovulation the remains of the ruptured follicle undergo important changes which convert it into the corpus luteum. In the absence of fertilization, the functional capacity of the corpus luteum only persists for about 10 days before degenerative changes set in. During the late luteal phase, the lutein cells undergo lipolysis and atrophy. Eventually, the corpus luteum is converted into a hyaline body, the corpus albicans. The present study demonstrated that in corpora lutea during the early and mid luteal phase, myc oncoprotein expression is totally negative in the lutein cells, whereas in regressing corpora lutea during the late luteal phase, myc oncoprotein expression is apparent in the peripheral theca lutein cells adjacent to the central core of scar tissue. The fate of remnant theca lutein cells after luteolysis is not clear. Nevertheless, this observation in the regressing cor- 

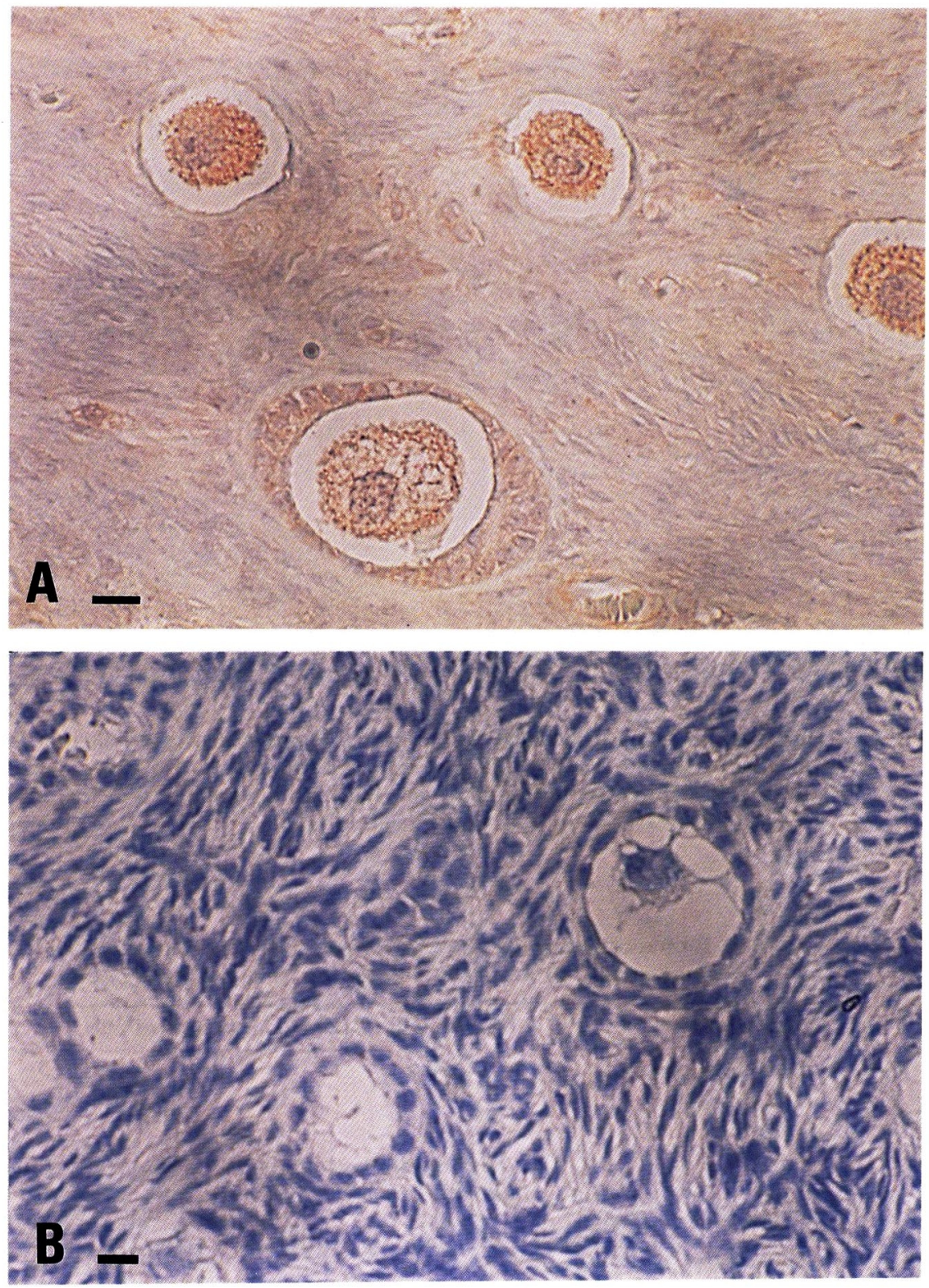

Fig. 1. Immunohistochemical localization of myc oncoprotein in primordial follicles and preantral follicles. In primordial follicles only the oocyte showed intense immunostaining for myc protein (A), whereas in preantral follicles both the oocyte and granulosa cells were moderately immunostained for myc protein (A). Preincubation of the primary antibody with human myc peptide showed a lack of positive immunostaining of the oocyte and granulosa cells for myc protein (B). Bars represent $5 \mu \mathrm{m}$. (Original magnification $\times 400$ ).

pora lutea implies that $m y c$ oncoprotein expression may participate in remodelling the ovarian local tissue through the incorporation of remnant theca lutein cells into the stroma following luteolysis.

On the other hand, the majority. of developing follicles are known to undergo atresia. It has re- cently become evident that apoptosis is responsible for the demise of granulosa and theca cells during follicular atresia $[25,26]$. The results of the present study indicate that appreciable expression of $m y c$ oncoprotein is apparent in the scattered granulosa cells and theca interna cells of atretic follicles. Con- 


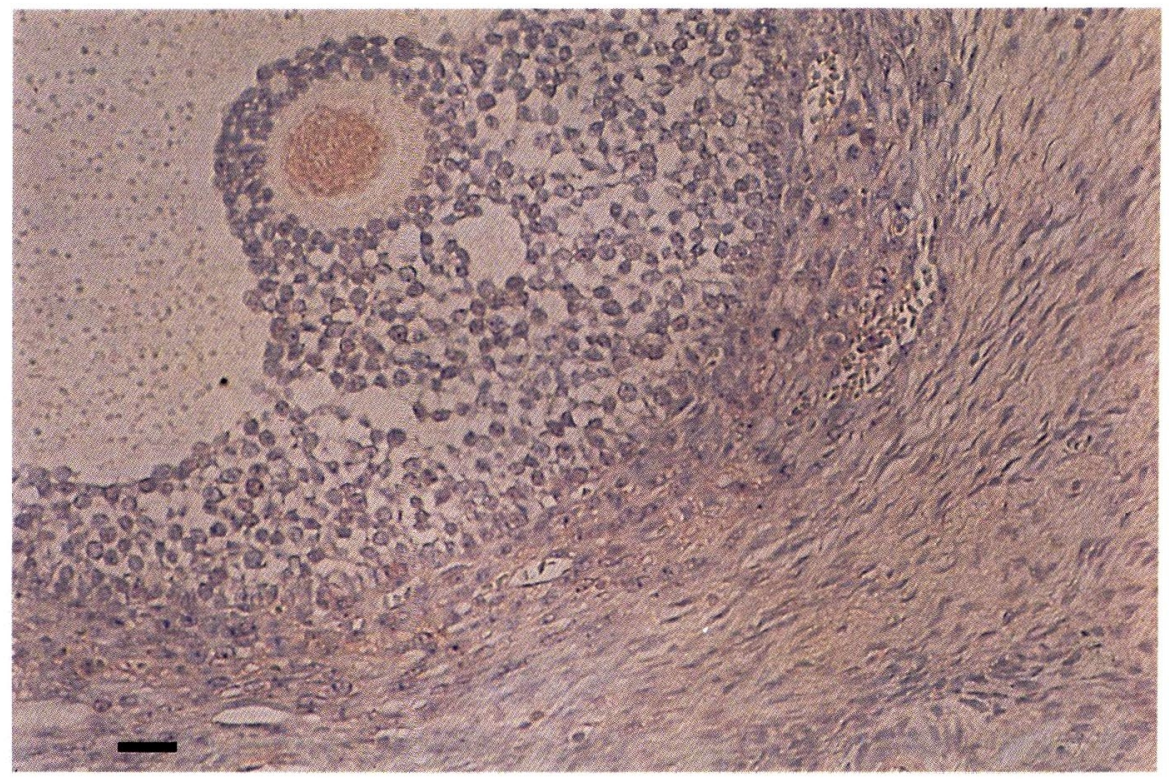

Fig. 2. Immunohistochemical localization of myc oncoprotein in antral follicles. Only the oocyte showed moderate immunostaining for myc protein, but no appreciable staining for $m y c$ protein was found in the granulosa or theca cells. Bar represents $10 \mu \mathrm{m}$. (Original magnification $\times 200$ ).

Table 2. Immunostaining for $m y c$ oncoprotein in luteal cells and the surrounding stromal cells over the course of the luteal phase

\begin{tabular}{lcc}
\hline Luteal phase & Luteal cells & Surrounding stromal cells \\
\hline Early phase $(n=3)$ & - & - \\
Mid phase $(n=3)$ & - & - \\
Late phase $(n=3)$ & + & - \\
& $\begin{array}{c}\text { (positive in peripheral } \\
\text { theca lutein cells) }\end{array}$ \\
Corpus albicans $(n=3)$ & - & -
\end{tabular}

Legends are as in Table 1.

sequently, this suggests the intriguing possibility of $m y c$ expression involvement in the process of apoptosis during follicular atresia and/or the incorporation of surviving granulosa and theca cells from atretic follicles into the ovarian stroma to form interstitial tissue.

Similar patterns of expression in the peripheral theca lutein cells of regressing corpora lutea and in the theca interna cells of atretic follicles as observed with myc oncoprotein have been shown with EGF receptor [16] and insulin receptor [27]. Taken together, it is possible that EGF, insulin and myc oncoprotein in combination may participate in remodelling the ovarian local tissue following luteolysis and artresia.

In conclusion, our observations provide a new insight into the role of $m y c$ oncoprotein expression in the initial growth of the oocyte in early folliculogenesis, the autonomous growth of granulosa cells during the preantral follicle stage and in remodelling the ovarian local tissue following atresia and luteolysis in the human ovary. 


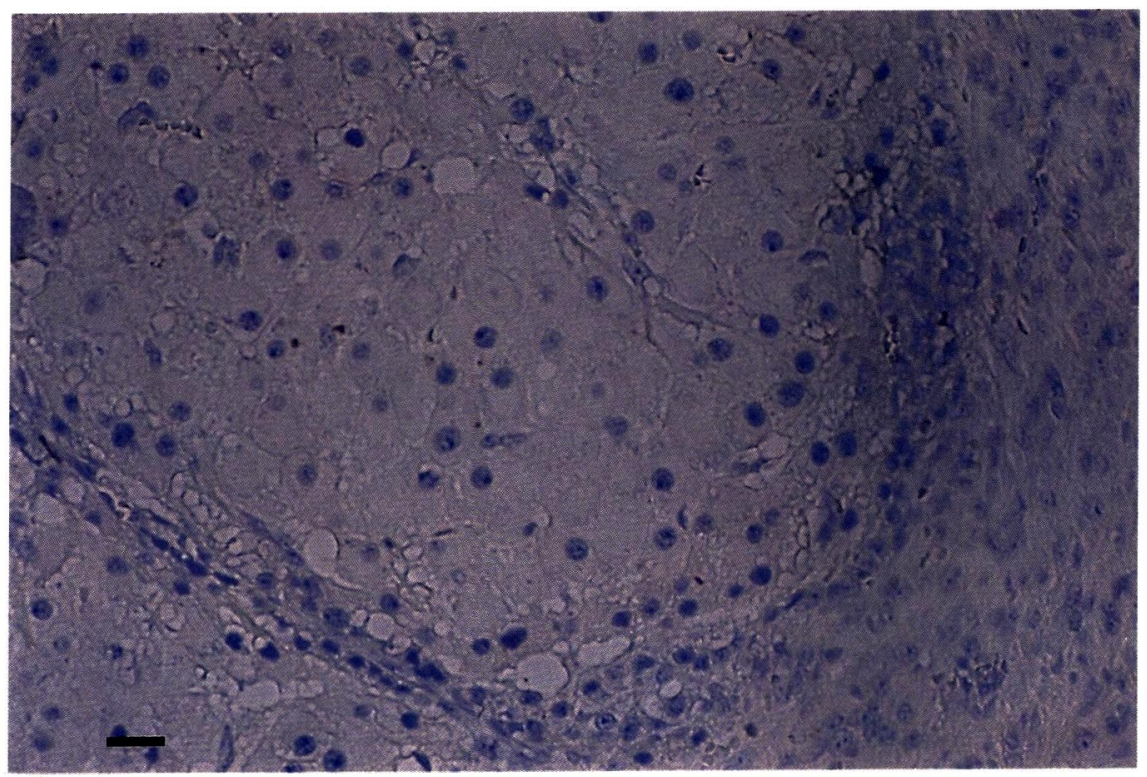

Fig. 3. Immunohistochemical localization of myc oncoprotein in the corpus luteum of the midluteal phase. Luteal cells were negative for immunostaining for myc protein. Bar represents $10 \mu \mathrm{m}$. (Original magnification $\times 200$ ).

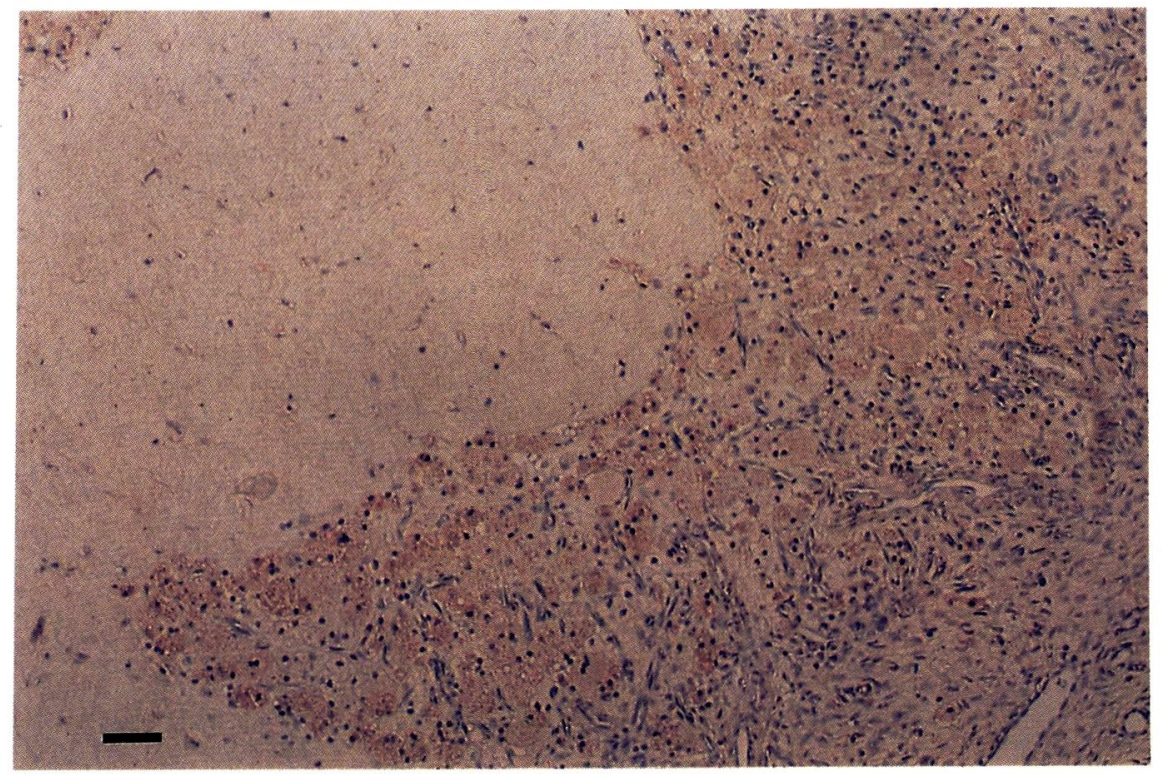

Fig. 4. Immunohistochemical localization of myc oncoprotein in the regressing corpus luteum of the late luteal phase. Theca luteal cells surrounding the central core of scar tissue were positively immunostained for $m y c$ protein, whereas the central core of scar tissue was negative for immunostaining for myc protein. Bar represents $10 \mu \mathrm{m}$. (Original magnification $\times 200$ ). 


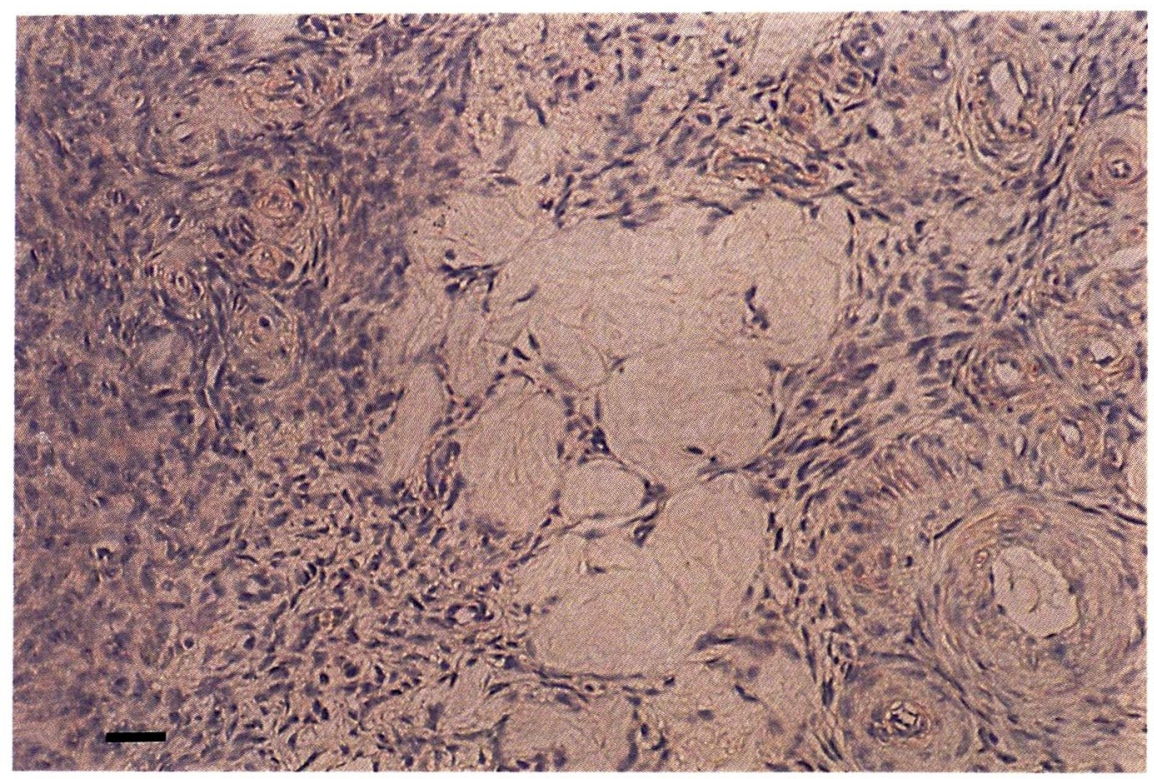

Fig. 5. Immunohistochemical localization of myc oncoprotein in the corpus albicans. The corpus albicans and surrounding stromal cells were totally negative for $m y c$ protein immunostaining. Bar represents $10 \mu \mathrm{m}$. (Original magnification $\times 200$ ).

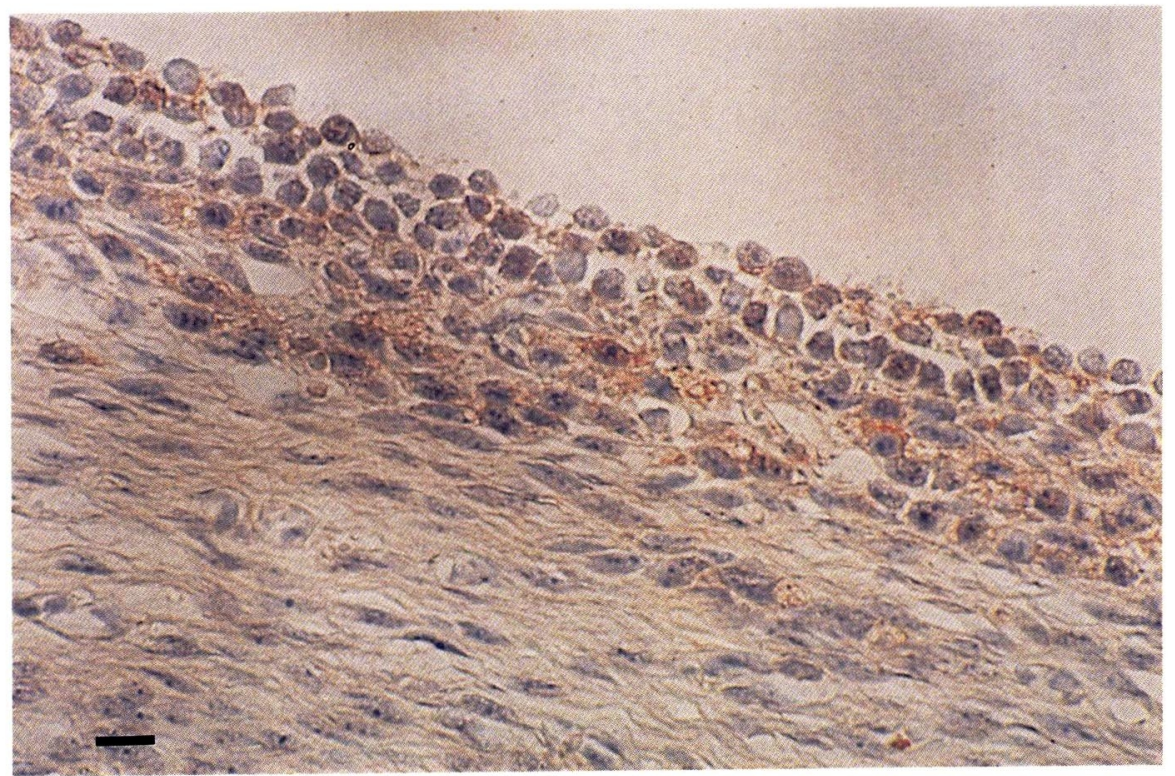

Fig. 6. Immunohistochemical localization of myc oncoprotein in atretic follicles. The scattered granulosa cells and theca interna cells displayed weak but definitely positive immunostaining for myc protein, whereas the surrounding stromal cells were negative for staining for myc protein. Bar represents $5 \mu \mathrm{m}$. (Original magnification $\times 400)$. 


\section{Acknowledgments}

This work was supported in part by Grant-inAid for Scientific Research 0267074 and 05454451 from the Japanese Ministry of Education, Science and Culture, the Ogyaa-Donation Foundation of the Japan Association of Maternal Welfare, and International Committee of the Population Council (New York, NY, USA). S. Li and C. A. LadinesLlave were supported by the Morinaga-Sakamoto Research Fund for Population Sciences and by the Rompaku Program of the Japan Society for the Promotion of Science, respectively.

\section{References}

1. Hsueh AJW, Adashi EY, Jones PBC, Welsh TH Jr (1984) Hormonal regulation of the differentiation of cultured ovarian granulosa cells. Endocr Rev 5: 76-127.

2. Maruo T, Hayashi M, Matsuo $H$, Yamamoto T, Okada H, Mochizuki M (1987) The role of thyroid hormone as a biological amplifier of the actions of follicle-stimulating hormone in the functional differentiation of cultured porcine granulosa cells. Endocrinology 121: 1233-1241.

3. Mochizuki M, Maruo T (1988) Thyroid hormone synergizes with follicle-stimulating hormone in the expression of differentiated functions of porcine granulosa cells. In: Ichinoe K, Segal SJ, Matroianni L (eds) Preservation of Tubo-Ovarian Function in Gynecologic Benign and Malignant Diseases. Raven Press, New York : 69-84.

4. Maruo T, Hiramatsu S, Otani T, Hayashi M, Mochizuki M (1992) Increase in the expression of thyroid hormone receptors in porcine granulosa cells early in follicular maturation. Acta Endocrinol (Copenh) 127: 152-160.

5. May JV, Schomberg DW (1981) Granulosa cell differentiation in vitro: Effect of insulin on growth and functional integrity. Biol Reprod 25: 421-431.

6. Veldhuis JD, Kolp LA, Toaff ME, Strauss JF, Demers LM (1983) Mechanisms subserving the trophic actions of insulin on ovarian cells: in vitro studies using swine granulosa cells. J Clin Invest 72: 1046-1057.

7. Otani T, Maruo T, Mochizuki M (1985) Effect of insulin on porcine granulosa cells: implications of a possible receptor mediated action. Acta Endocrinol (Copenh) 108: 104-110.

8. Davoren JB, Hsueh AJW (1984) Insulin enhances FSH-stimulated steroidogenesis by cultured rat granulosa cells. Mol Cell Endocrinol 35: 97-105.

9. Adashi EY, Resnick CE, D'Erocle AJ, Svoboda ME, Van Wyk JJ (1985) Insulin-like growth factors as intraovarian regulators of granulosa cell growth and function. Endocr Rev 6: 400-420.

10. Veldhuis JD, Furlanetto RW (1985) Tropic action of human somatomedin-C/insulin-like growth factor I on ovarian cells: in vitro studies with swine granulosa cells. Endocrinology 116: 1235-1242.

11. Maruo T, Hayashi M, Matsuo H, Ueda $Y$, Morikawa H, Mochizuki M (1988) Comparison of the facilitative roles of insulin and insulin-like growth factor-I in the functional differentiation of granulosa cells: in vitro studies with the porcine model. Acta Endocrinol (Copenh) 117: 230-240.

12. Gospodarowicz D, Bialeck H (1979) Fibroblast and epidermal growth factors and mitogenic agents for cultured granulosa cells of rodent, porcine and human origin. Endocrinology 104: 757-764.

13. Jones PBC, Welch Jr TH, Hsueh AJW (1982) Regulation of ovarian progestin production by epidermal growth factor in cultured rat granulosa cells. $J$ Biol Chem 257: 11268-11273.

14. May JV, Buck PA, Schomberg DW (1987) Epidermal growth factor enhances ${ }^{125} \mathrm{I}$-follicle stimulating hormone binding by cultured porcine granulosa cells. Endocrinology 120: 2413-2420.

15. Hiramatsu S, Maruo T, Matsuo H, Mochizuki M (1992) Effects of epidermal growth factor on the proliferation and differentiation of porcine granulosa cells cultured in vitro. Acta Obstet Gynecol Jpn 44: 55-61.

16. Maruo T, Ladines-Llave CA, Samoto T, Matsuo H, Manalo AS, Ito H, Mochizuki M (1993) Expression of epidermal growth factor and its receptor in the human ovary during follicular growth and regression. Endocrinology 132: 924-931.

17. Gospodarowicz D, Birdwell III CR (1977) Effects of fibroblast and epidermal growth factors on ovarian cell proliferation in vitro. Endocrinology 100: 11081114.

18. Land H, Parada LF, Wernberg RA (1983) Cellular oncogenes and multistep carcinogenesis. Science 222: 771-775.

19. Pfeifer-Ohlsson S, Goustin AS, Rydnert J, Wahlstrom T, Bjersing L, Stehelin D, Ohlsson R (1984) Spatial and temporal pattern of cellular myc oncogene expression in developing human placenta: implications for embryonic cell proliferation. Cell 38: 585-596.

20. Maruo T, Mochizuki M (1987) Immunohistochemical localization of epidermal growth factor receptor 
and myc oncogene product in human placenta: implication for trophoblast proliferation and differentiation. Am J Obstet Gynecol 156: 721-772.

21. Noyes RW, Hertig AT, Rock J (1950) Dating the endometrial biopsy. Fertil Steril 1: 3-25.

22. Baker TG, Franchi LL, O WS (1991) The ovary: development and structure. In: Philipp E (ed) Scientific Foundations of Obstetrics and Gynecology. Butterworth/Heinenmann, New York : 145-171.

23. Zeleznik AJ, Schuler HM, Reichert LE (1981) Gonadotropin-binding sites in the rhesus monkey ovary: Role of the vasculature in the selective distribution of human chorionic gonadotropin to the preovulatory follicle. Endocrinology 109: 256-264.

24. Ericson GF (1978) Normal ovarian function. Clin
Obstet Gynecol 21: 31-41.

25. Tilly JL, Kowalski KI, Johnson AL, Hsueh AJW (1991) Involvement of apoptosis in ovarian follicular atresia and postovulatory regression. Endocrinology 129: 2799-2801.

26. Hughes FM, Gorospe WC (1991) Biochemical identification of apoptosis in granulosa cells: Evidence for a potential mechanism underlying follicular atresia. Endocrinology 129: 2415-2422.

27. Samoto T, Maruo T, Ladine-Llave CA, Matsuo $H$, Deguchi J, Barnea ER, Mochizuki M (1993) Insulin receptor expression in follicular and stromal compartments of the human ovary over the course of follicular growth, regression and atresia. Endocrine J 40: 715-726. 